\title{
Türkiye'de Kalkınmaya Yönelik Ekonomik Politikalara Eleştirel Bir Bakış
}

\author{
DOI: $10.26466 /$ opus.487943 \\ Mahmut Küçükoğlu - Hac1 Yunus Taș ${ }^{* *}-$ Hüseyin Ercan ${ }^{* * *}$ \\ * Dr. Öğr. Üyesi.Yalova Üniversitesi, İiBF, İktisat Bölümü, Yalova/Türkiye \\ E-Posta: mahmut.kucukoglu@yalova.edu.tr ORCID: 0000-0002-8286-6929 \\ ** Doç. Dr. Yalova Üniversitesi, İ̈BF, Çalışma Ekonomisi Bölümü, Yalova/Türkiye \\ E- Posta: yunus.tas@yalova.edu.tr ORCID: $0000-0003-3163-9416$ \\ ${ }^{* * *}$ Doktorant, Harran Üniversitesi, Maliye, Şanlıurfa/Türkiye \\ E- Posta: huseyin.ercan@inonu.edu.tr \\ ORCID: $\underline{0000-0003-2641-3674}$
}

Öz

Kalkınma kavramı, büyüme kavramından daha geniş kapsamlı bir kavram olup, azgelişmiş bir toplumun ekonomik yapısındaki değişikliklerle birlikte sosyal, kültürel ve siyasal yapıların da meydana gelen değişimi de ifade etmektedir. İktisadi büyüme ise, bir ülkenin genellikle bir yıl içinde üretim hacminde veya reel gayrisafi yurtiçi hasılasında görülen ve rakamsal olarak ölçülebilen artışları ifade eder. Kalkınmada kendiliğinden meydana gelecek değişmelere önceden müdahale edilerek bunlarm yönlendirilmesi söz konusu iken, büyümede bir müdahale söz konusu değildir. Cumhuriyetin kuruluşundan gönümüze kadar geçen yüzyillık bir süre içinde kamu kesimi ile kalkınma çabaları genel olarak iki döneme ayrilabilir. Birinci dönemde ekonominin kapasitesi de zorlanarak ciddi kalkınma ve gelişme girişimlerinin yapıldığı söylenebilir. Ayrıca bu dönemde ekonomik gelişme ile birlikte sosyal kalkınmaya da özen gösterilmeye çalışılmıştır. İkinci dönemde ise kalkınma ve yatırım çabaları daha çok piyasanın kendi şartlarına bırakılarak, özel kesimin gelişimi ile birlikte kalkınmanın sağlanabileceği görüşü benimsenmiştir. Bu çalışmada, kalkınma ve büyüme ilişkisi üzerinde durularak, son yıllarda ekonomik gelişmeleri ile öne çıkan ve çekim merkezi haline gelmeye başlayan özellikle Çin, Rusya, Hindistan, Brezilya ve gelişmiş bazı dünya ülkelerinin insani gelişme göstergeleri ve rekabet gücü açısından Türkiye ile karşılaştırarak Türkiye ekonomisi ile ilgili değerlendirmeler yapılmaya çalışılacaktır.

Anahtar Kelimeler: Büyüme ve Kalkınma, İnsani Gelişme Göstergesi, Kalkınma Planları, Kalkınma Politikaları 


\title{
A Critical Look for Economic Development Policy in Turkey
}

\begin{abstract}
The concept of development is broader than growth and refers to the change in the economic structure of an underdeveloped society, as well as to change its social, cultural and political structures. Economic growth is a real increase in a country's production capacity or real gross domestic product, which can be measured quantitatively. There is no intervention in growth, while the changes that occur spontaneously in the development will be intervened and directed. Growth does not necessarily require structural change in that economy. The public sector and development efforts can be divided into two periods, from the establishment of the Republic to the present. In the first period, the capacity of the economy is also challenged and serious development and development initiatives can be made. In this period, social development was tried to be taken care of together with economic development. In the second period, the development and investment efforts were mostly left to the market conditions and the development of the private sector was adopted. In this study "development and emphasis on growth relationship, highlighted by the economic developments in recent years and started to become a center of attraction especially China, Russia, India, Brazil and some advanced countries of the world by comparing human development indicators and Turkey in terms of competitiveness with Turkey's economy related evaluations will be made.
\end{abstract}

Keywords: Growth and Development, Human Development Indicator, Development Plans, Development Policies 


\section{Giriş}

Rostow 1960 yılında yazdığı Ekonomik Büyümenin Aşamaları isimli eserinde batı ülkelerinin yaşadıkları deneyimlere bakarak sanayileşmiş ülkelerin beş aşamadan geçtiklerini ileri sürmektedir. Bu aşamalar Geleneksel Toplum Aşaması, Kalkışa Hazırlık Aşaması, Kalkış Aşaması, Olgunluk Aşaması ve Kitle Tüketim Aşamasıdır. İngiltere 1850'de, Amerika 1900'de, Almanya 1910, Japonya 1940, Rusyanin ise 1950 yılında olgunluk aşamasına ulaştığı ifade edilmektedir. Türkiye için 1937 yılını Kalkış Aşaması olarak değerlendiren Rostow, Kalkış döneminin sona ermesinden 40 yıl sonra olgunluk aşamasına ulaşılacağını belirtmiş ve bu hesaba göre Türkiye'nin 1977'de olgunluk aşamasına ulaşmış olması gerekmektedir. Olgunluk aşamasında ulusal gelirin yüzde 10-20'si yatırım harcamalarına gideceği kabul edilmektedir. Türkiye açısından bakarsak 2016 yılında toplam yatırım harcamalarının GSYIH içindeki payı \%28,2'dir, bu oranın \% 4,1'i kamu yatırım harcamaları \%24,1'i özel yatırım harcamalarıdır. İnsani Gelişme Göstergesi 2016 Raporuna göre 188 ülke değerlendirmeye alınmıştır. $\mathrm{Bu}$ sınıflandırmaya göre çok yüksek İGG, yüksek İGG, orta İGG, düşük İGG şeklinde sınıflandırma yapılmıştır. Bu sınıflandırmaya göre Türkiye yüksek IGG yer almaktadır. Türkiye'de planlama anlayışı 1930'lu yıllarda hazırlanan sanayi planları ile başlamış, Devlet Planlama Teşkilatının kurulduğu tarihten günümüze kadar on adet Beş Yıllık Kalkınma Planı hazırlanmış ve uygulamaya konulmuştur. 2019 yılından itibaren on birinci Kalkınma Planı uygulanmaya başlanacak ve 2023 yılına kadar geçerli olacaktır.

\section{Kalkınma Kavramı ve Kalkınma Politikalari}

\subsection{Kalkınmanın Tanımı}

Kalkınma kavramı, büyümeden daha geniş kapsamlı olup, azgelişmiş bir toplumun iktisadi yapısının değişmesi yanında sosyal, kültürel ve siyasal yapılarında değiştirilmesini, yenileştirilmesini ifade etmektedir. Kişi başına düşen milli gelirin artması yanında, genel olarak üretim faktörlerinin etkinlik ve miktarlarının değişmesi, sanayi kesiminin milli gelir ve ihracat içindeki payının artması gibi yapısal değişiklikler, 
kalkınmanın temel unsurlarını oluşturur (Taban ve Kar, 2014, s.3-4). Ekonomik kalkınma sorunu, kapitalizmin ilk aşamalarında gündeme gelmekte ve zaman içinde ekonomik büyüme ile oluşan sosyal gelişme ve ekonomik bolluk sonucunda yerini ekonomik büyümeye birakmaktadır. Diğer bir deyişle, ekonomik kalkınma bir ekonomide sonsuza kadar devam ettirilecek bir politika olmayıp, zamanla sınırlıdır (Pınar, Önder ve Gümüş, 2015, 81).

\subsection{Büyümenin Tanımı}

İktisadi büyüme, bir ülkenin genellikle bir yıl içinde üretim kapasitesinde veya reel gayrisafi yurtiçi hasılasında görülen ve sayısal olarak ölçülebilen reel artışlardır. Kişi başına gelir açısından bakıldığında büyüme, hem bir toplumdaki ekonomik faaliyetlerin ölçeğinde meydana gelen artışları hem de kişi başına gelir artışını ifade etmektedir. Bu yüzden büyüme, makroekonomik açıdan arz cephesinde belirlenir. Arz eğrisinin sağa kayması ya da üretim olanakları eğrisinin sağa kayması ile ifade edilir. Kişi başına reel gelir veya hasılada meydana gelen artışın büyüme olarak nitelendirilebilmesi için, bu artışın geçici olmaması, yani sürekli olması gerekir. Dolayısıyla iktisadi büyüme kısa dönemli statik bir olgu değil, uzun dönemli dinamik bir olgudur. Kısa dönemde üretimin ne kadar arttığına yönelik tahminler yapılabilir fakat ekonominin nasıl bir seyir izleyeceği, gerçek yapısı ve yapısal değişimi hakkında yeterli bilgiye ulaşılamaz. Uzun dönemde ise iktisadi büyümede uzun yılları içine alan bir perspektifte meydana gelen değişiklikler esas alınmaktadır (Taban v.d., 2013, s.4).

\subsection{Kalkınma ve Büyüme İlişkisi}

Büyüme ve kalkınma arasında en önemli fark, büyümede mevcut yapı esas alınırken, kalkınmada mevcut ekonomik yapıya razı olunmamakta, bunun değiştirilerek geliştirilmesi esas alınmaktadır. Kalkınmada kendiliğinden meydana gelecek değişmelere baştan müdahale edilerek bunların yönlendirilmesi söz konusu iken, büyümede bir müdahale söz konusu değildir. Büyüme mutlaka o ekonomide yapısal değişimi gerektirmez. Büyüme nitelikten çok niceliksel açıdan ortaya çıkan bir değişi- 
kliktir, üretimin ve kişi başına düşen gelirin reel olarak artırılmasıdır. Gelirin artmış olması gelir dağılımının da düzgün olduğu anlamına gelmez. Petrol zengini Kuveyt, Katar gibi ülkelerde kişi başına düşen gelir gelişmiş ülkelerdeki gibi yüksek olsa da yaşam standartları açısından farklılıklar vardır. Bir ülkedeki refah artışından ve kalkınmanın genel düzeyinden bahsedebilmek için gelir dağılımının da göz önünde bulundurulması gerekir. Bir ülkede kişi başına düşen gelirin çok yüksek oranda artmış olmasından nüfusun az bir bölümü yararlanıyorsa o zaman nüfusun büyük bir kısmının yaşam düzeylerinde herhangi bir yükselme olmayacaktır. Böyle bir durumda büyümeden söz edilirken, kalkınmadan söz edilmeyecektir. Yani kalkınma olmadan büyüme gerçekleşmiş olmaktadır. Ancak böyle bir durum az gelişmiş ülkeler için istenilen bir durum değildir. Bu ülkeler için amaçlanan, büyümeyle beraber kalkınmanın da gerçekleşmesi sosyal, siyasal ve kültürel gelişiminde gerçekleşmesidir (Taban ve Kar,2014, s.4)

Bir ülkenin kalkınması ve büyümesi, kesinlikle birbiri ile ilişkili olmakla birlikte, biri sadece ekonomik göstergelerde, diğeri ise ekonomik ve sosyal göstergelerde ifadesini bulan iki farklı ölçütle değerlendirilir.

\section{4. İnsani Gelişme Göstergesi}

İnsani Gelişme Göstergesi (İGG) ülkelerde izlenen yaşam uzunluğu, okuryazar oranı ve yaşam kalitesi göstergelerini içeren bir ölçümdür. Bu ölçüm sonucunda ülkeler gelişmişlik göstergelerine göre sıralanarak, ülkelerin gelişmiş ya da gelişmemiş oldukları hakkındaki bilgiler oluşturulmaktadır. Göstergede yer alan katsayılar 1990 yılında Pakistanlı ekonomist Mahbub ul Haq tarafından geliştirilmiştir ve 1993 yılından itibaren Birleşmiş Milletler Gelişme Programı tarafından hesaplanarak yayınlanmaktadır. İnsani Gelişme Göstergesi ülkelerdeki başlıca üç gelişimleri dikkate alır.

- Uzun ve sağlıklı bir yaşam; ölçümü, ortalama yaşam süresi ile yapilir.

- Bilgi; ölçümü, okur yazar oranı ve ilkokul, lise ve üniversite dereceleri ile yapilır. 
- Yaşam düzeyi; ölçümü, kişi başına düşen gelir ve alım gücünün ABD doları ile yapılır (Pınar, Önder, Gümüş.,2015, s.68)

Tablo 1. Türkiye'nin Yıllar İtibariyle İnsani Gelişme Göstergesi

\begin{tabular}{|l|c|c|c|}
\hline Yillar & $\begin{array}{c}\text { İnsani Gelişme Göster- } \\
\text { gesi }\end{array}$ & Sıra & Ülke Sayıs1 \\
\hline 1980 & 0,467 & 57 & 95 \\
\hline 1990 & 0,552 & 71 & 119 \\
\hline 2000 & 0,629 & 68 & 139 \\
\hline 2015 & 0,767 & 71 & 188 \\
\hline
\end{tabular}

Kaynak: Pınar, 2015:68 ve Human Development Report 2016. (Erişim Tarihi: 01.12.2017).

Tablodan anlaşıldığı gibi İnsani Gelişme Göstergesi Yıllar itibariye iyiye doğru giderken ülke sayısındaki artış da dikkate alındığında sıralama fazla değişmemiştir.

Tablo 2. 2015 yılı Türkiye'nin İnsani Gelişme Göstergesi ve Bazı Ülkelerle Karşılaştırnlması

\begin{tabular}{|l|c|c|c|c|c|c|}
\hline Ülke & $\begin{array}{c}\text { İnsani } \\
\text { Gelişme } \\
\text { Göstergesi }\end{array}$ & $\begin{array}{c}\text { Yaşam } \\
\text { Beklentisi }\end{array}$ & $\begin{array}{c}\text { Beklenen } \\
\text { Okullaşma } \\
\text { Yll }\end{array}$ & $\begin{array}{c}\text { Okullaşma } \\
\text { Y1lı }\end{array}$ & $\begin{array}{c}\text { Kişi Başına } \\
\text { Gelir } \\
\text { Dolar }\end{array}$ & $\begin{array}{c}\text { Sıra } \\
2015\end{array}$ \\
\hline Norveç & 0,949 & 81,7 & 17,7 & 12,7 & 67.614 & 1 \\
\hline Türkiye & 0,767 & 75,5 & 14,6 & 7,9 & 18.705 & 71 \\
\hline Çin & 0,738 & 76,0 & 13,5 & 7,6 & 13.345 & 90 \\
\hline Brezilya & 0,754 & 74,7 & 15,2 & 7,8 & 14.145 & 79 \\
\hline Hindistan & 0,624 & 68,3 & 11,7 & 6,3 & 5.663 & 131 \\
\hline Rusya & 0,804 & 70,3 & 15,0 & 12,0 & 23.286 & 49 \\
\hline
\end{tabular}

Kaynak: Human Development Report 2016. (Erişim Tarihi: 01.12.2017).

Tabloya göre Türkiye'yi Norveç hariç diğer ülkelerle karşılaştırdığımızda Türkiye'den daha iyi durumda olan ülke 49. Sırada yer alan Rusya'dır. Grup olarak baktığımızda Türkiye, Brezilya ve Çin Yüksek İnsani Gelişme grubunda yer almaktalar, Rusya ise, Norveç'le beraber Çok Yüksek İnsani Gelişme grubunda yer almaktadır. Rusya'nın Türkiye'den iyi durumda olmasında kişi başına gelirinin yüksek olması etkili olmaktadir. 


\subsection{Kalkınma Planları}

Piyasa ve fiyat mekanizmasının azgelişmiş ülkelerde kaynak dağılımı ve yönlendirme fonksiyonlarını yerine getirememesi, bu ülkelerin kalkınmalarını gerçekleştirebilmeleri için önceden tasarlanmış, düzenli, rasyonel, diğer bir deyişle planlama anlayışının olması gerekir.

Özellikle İkinci Dünya Savaşı sonrası yıllarda piyasa ekonomisinin iktisadi ve sosyal gelişmenin önündeki engelleri ortadan kaldıramadığını gören birçok ülke, kalkınma planlarıyla geleceğin belirsizliğini en aza indirerek bir taraftan özel sektöre doğru kararlar alabilme olanağı sağlarken diğer taraftan devletin etkinlik ve müdahalesini rasyonel bir ekonomi politikası çerçevesinde yapılmasını disipline etmeye çalışmıştır. Planlama anlayışı, sorumlu devletin sosyo-ekonomik süreci düzenlemesinin ve kıt kaynakları etkin kullanarak, giderek artan görevlerini daha verimli yerine getirmesinin bir aracı olarak gelişmiştir (Taban ve Kar, 2014, 221).

Kalkınma planlaması, uzun dönemli kalkınma politikasının belli kurallara göre düzenlenmesi demektir. Genel bir tanım verecek olursak kalkınma planlaması bir ülkede geçerli ekonomik, sosyal ve siyasal değer yargıları 1şı̆̆ında, belirli bir dönemde toplumun ulaşmak istediği sosyo-ekonomik amaçlara ve sayısal olarak belirlenmiş hedeflere en uygun bir biçimde varmak için, kaynakların belirli organlar tarafından yönetilmesi sürecidir diyebiliriz (Özdemir, https://dumludag.files.wordpress.com/20-13/09/ozdemir_planlama.pdf,:3 (Erişim Tarihi: 01.12.2017)

Kalkınma planları; ekonominin bütününü, ekonomik ve sosyal faktörler arasındaki ilişkileri, uzun vadeli anlayışla ele alan, kamu kesimi için emredici, özel kesim için de orta ve uzun vadede yol gösterici, hukuki ve teknik şartlara haiz makro planlardır. Planlarda amaç, ekonomik ve sosyal yapının planda öngörülen süre sonunda hedeflenen düzeye ulaşmasını sağlamaktır. Bu çerçevede, ekonomik büyümeyi sağlayarak kişi başına düşen geliri ve istihdamı artırmak, gelir dağılımı ve bölgelerarası dengesizliği gidermek, ödemeler bilançosu açılarını azaltmak gibi ekonomik hedeflerle birlikte; toplumun refah düzeyini artırmak, eğitim düzeyini yükseltmek, bilim ve teknolojiyi geliştirmek, dış ülkelerle sağlıklı ilişkileri sürdürmek gibi ekonomik olmayan birçok hedef de gerçekleştirilmeye çalışılmaktadır (Takım, 2011, s.155). 


\section{Brezilya, Rusya, Hindistan, Çin Ve Bazi Gelişmiş Ülkelerde Kalkinma Politikalari}

\section{1. Çin}

Çin, Asya'nın doğusunda, Pasifik Okyanus'un batı kıyısında, Rusya ve Kanada'dan sonra yüzölçümü olarak dünyanın üçüncü büyük, 1,3 milyar nüfusu itibariyle de en kalabalık ülkedir. 9,6 milyon kilometre kare yüzölçümüne sahiptir. Bu geniş kara parçasının yüzde 70'i dağ ve çöllerden oluşmakta, tarıma elverişli arazi ancak yüzde 30'luk bir alandan oluşmaktadır. Tarıma elverişli alanlar, nüfusla karşılaştırıldığında oldukça düşük kalmaktadır. Çin uzun yıllar köylü toplumu olarak görülmüş fakat bu özelliğini yitirmekte, huzla kentleşmektedir. Çin ekonomisinin hızlı bir şekilde büyümesi ve dünya dengelerini etkilemesi açısından 1978 yılından sonra atılan adımların rolü büyük olmuştur. Özellikle diş ticaret açısından liberal politikalar uygulanması, ithalat kontrolleri, tarım sektöründe ve KİT'lerde yaşanan reform süreci etkileyici olmuştur (Özsoylu, 2009, s.56).

19.Yüzyılın ilk çeyreğinde Çin GSYİH değerleriyle dünyanın en büyük ekonomisi iken, bu dönemden sonra çok hızlı bir ekonomik düşüş yaşamaya başlamıştır. Çin ekonomisi 19. Yüzyıldan sonra Avrupa da gelişen sanayi ve askeri teknolojilerden olumsuz etkilenmiştir. 19. Yüzyılın başlarına kadar dünyanın diğer bölgelerine göre oldukça gelişmiş bir ülke olan Çin, batıdaki sanayileşme devrimi sonrasında Avrupalı devletlerin yakaladığı teknolojik gelişim ve deniz aşırı ticaret karşısında duramamış ve değişime ayak uyduramayarak hızlı bir çöküş süreci yaşamıştır. (Sandıklı, 2009, s.41).

Çin ekonomisini reformlara yönelten temel faktörleri şu şekilde sıralayabiliriz. 1)Mao'nun kültür devriminin giderek halkın desteğini kaybetmesi, 2) Uzun ylllara dayanan devlet planlı uygulamalarının kıtlıklarla baş edememesi, 3) Öteki Uzakdoğu ülkelerinin (Tayvan, Hong Kong, Singapur, Güney Kore) uyguladıkları piyasa ekonomisinin göreceli olarak başarılı sonuçlar elde etmesidir. Sosyalist piyasa ekonomisine geçen Çin'in reform sürecinde üzerinde durduğu konulardan biride; "Bilgiye ve öğrenmeye açıklık ve deneyimlerden yararlanma" yönt- 
emidir. Bu yöntem, Çin gelişiminin temel unsurlarından biri olan üretim yapısının değişimini ve gelişimini desteklemiştir. Özellikle, diğer ülkelerin deneyimlerinden yararlanma ve daha öncesinde hiçbir tecrübesi bulunmayan sektörlerde benzetme ve tutundurma çabaları Çin'de hızlı gelişimin bir parçası olarak görülmüştür (Tosun,2014, s.33).

Çin'in ekonomik büyümesini "cia-hane"lar sağlamış, fakat bu büyümeyi devlet yönlendirmiştir. Mülkiyet sistemi, teknolojik yapılanma, ekonomik büyüme hızı hep devlet tarafından belirlenmiştir. Fazla zenginleşmek mümkün olmamış ayrıca izinde verilmemiştir. Örneğin bir cia'ın çalıştırabileceği mekik sayısı devlet tarafından belirlenmiş, bu sayıdan fazla mekik sayısının ancak devlet imalathanelerinde gerçekleştirilebileceği kararlaştırılmıştır. Başka bir örnek olarak, belli kalitenin üstündeki porselenin, ancak devlete ait fırınlarda üretimine izin verilmiştir (Özsoylu, 2009, s.59).

İlk iki beş yıllık planda Çin endüstriyel potansiyeli harekete geçirmeyi amaçlamış, bu sırada zaten düşük olan tüketim düzeyini korumuştur. Öncelik ağır endüstriye verilmiştir. 1953-1957 yılları arasında tarım net olarak endüstriye feda edilmiştir. Hafif ve gıda endüstrilerinde büyüme oranı yavaşlamıştır (Başoğlu ve Parasız, 2002, s.30).

22 Aralık 1978'de Çin hükümeti tarımsal etkinliğini artırmak amacıyla üç önemli karar almıştır. Bu kararlar: 1) Tahıl fiyatlarının alımında $\% 20$ 'lik bir reel artış yapmak 2) Devlet tarafından belirlenen kota üretiminde \%50'lik bir artış sağlamak 3) Tarımsal girdi fiyatlarında yaklaşık olarak \%10-15'lik oranında bir düşüş sağlamak.

Bir taraftan toprak reformu ile kırsal kesim güçlendirilmeye ve ülke için gerekli besin maddeleri üretiminde artış sağlanmaya çalışılırken, asıl amaç tarım toplumundan sanayi toplumuna geçiş olmuştur. Fakat içinde bulunulan ekonomik durum ve sanayi yapısı bu amacı gerçekleştirmeye uygun değildi. Stratejik önem arz eden sektörlerin kamulaştırılmasıyla sanayi sektörü önemli ölçüde devletin kontrolüne geçmiş, büyük sermaye sahipleri mülkiyetleri ellerinden alınarak özel sektör kontrol altına alınmış ve sermaye birikimi sağlanmaya çalışılmıştır (Özsoylu ve Algan, 2011, s.165).

Hükümet kâr etmeyen kamu işletmelerinden vergi almazken bu kurumlarda çalışan yöneticilerin ücretlerini de performansa bağlamıştır. Ayrıca, 1990'larda başlatılan yönetsel reformlar çerçevesinde başta 
ekonomiyi yönlendiren kamu işletmeleri olmak üzere merkezi yönetim personel kadroları yeniden yapılandırılmış, birleşmeler ve kaldırmalar yoluyla sayıları azaltılmıştır. Çin Halk Cumhuriyeti'nin "planlı ekonomiden" "sosyalist piyasa ekonomisine" geçişini hedefleyen reformların önemli bir ayağı kamu personel reformudur. Personel reformu, yeni ekonomik rejimin gereksindiği personel sistemini ve insan gücü modelini yaratmaya yöneliktir (Sezen, 2009, s.361).

Sermaye birikiminin yetersiz olmasından dolayı özel yabancı sermayeye önem verilmiş, yabancı sermaye ve teknoloji ülkeye çekmek için Özel Ekonomik Bölgeler oluşturulmuş (ÖEB), Deng'in izlemiş olduğu Açık Kapı politikası doğrultusunda kıyı bölgelerinde Guangdong ve Fujian'da dört tane ÖEB oluşturulmuştur. Kıyı şeridinde Hong Kong ve Tayvan'a yakın yerler seçilmiştir. Bu bölgelerde faaliyette bulunan yabancı firmalar kendi yatırım, üretim ve pazarlama faaliyetlerini yapabilmekte, çeşitli teşviklerden yararlanmaktadır. Yabancı yatırımcıların teknoloji transferi, yönetim tecrübesi, sermaye birikimi sağlama ve döviz kazandırma, altyapının gelişimine katkı sağlama açısından ekonomiye olumlu etkiler sağlama açısından Çin yabancı sermayeyi çekmek konusunda düzenlemeler yapmıştır (Özsoylu ve Algan, 2011, s.169).

Tablo 3. Çin'in Ekonomik Göstergeleri

\begin{tabular}{|l|c|c|c|c|c|}
\hline YILLAR & $\begin{array}{c}\text { GSYH } \\
\text { büyüme } \\
\text { oranı \% }\end{array}$ & $\begin{array}{c}\text { Tarım Sektö- } \\
\text { rünün Payı } \\
\text { \% }\end{array}$ & $\begin{array}{c}\text { Sanayi } \\
\text { Sektörünün } \\
\text { Pay1\% }\end{array}$ & $\begin{array}{c}\text { Kişi Başına } \\
\text { GSYİH }\end{array}$ & $\begin{array}{c}\text { Sermaye } \\
\text { Oluşumu }\end{array}$ \\
\hline 1978 & 11,66 & 27,68 & 47,71 & 200 & 38,40 \\
\hline 1980 & 7,80 & 29,63 & 48,05 & 220 & 35,38 \\
\hline 1985 & 13,44 & 27,93 & 42,71 & 290 & 39,89 \\
\hline 1990 & 3,90 & 26,58 & 41,03 & 330 & 34,73 \\
\hline 1995 & 10,94 & 19,59 & 46,75 & 540 & 39,68 \\
\hline 2000 & 8,49 & 14,67 & 45,53 & 940 & 34,43 \\
\hline 2005 & 11,39 & 11,64 & 47,02 & 1.740 & 41,39 \\
\hline 2010 & 10,63 & 9,53 & 46,39 & 4.340 & 47,61 \\
\hline 2015 & 6,90 & 8,83 & 40,93 & 7.940 & 45,40 \\
\hline 2016 & 6,69 & 8,55 & 39,81 & 8.260 & \\
\hline
\end{tabular}

Kaynak: World Bank Data. https://data.worldbank.org/indicator, (Erişim Tarihi: 23.11.2017)

Çin'in dışa açılmasının genişletilmesi ve yabancı sermaye için cazibe ortamı yaratılması adına Serbest Ticaret Bölgeleri kurularak ÖEB’lerden 
daha esnek politikaların uygulanmasına gidilmiştir. Pudong Shanghai bölgesinde ilk STB 1990 yılında faaliyete geçmiştir. Shanghai sadece Çin için değil tüm Asya bölgesi için temel ekonomi, ticaret ve finans merkezi olmuştur (Gautam v.d.,1996, s.5).

Tablo 4. Seçilmiş Ülkelerde İmalat Saat Başına İşgücü Maliyetleri (2011)

\begin{tabular}{|l|c|}
\hline ÜLKE İSMI & MALIYYET ABD DOLARI \\
\hline Norveç & 64,15 \\
\hline Almanya & 47,38 \\
\hline Fransa & 42,12 \\
\hline Japonya & 35,71 \\
\hline ABD & 35,53 \\
\hline Çin (2008) & 1,4 \\
\hline Hindistan (2007) & 1,2 \\
\hline
\end{tabular}

Kaynak: Bureau of Labor Statistics, https://www.bls.gov/news. release/pdflichcc.pdf, (Erişim Tarihi: 23.11.2017)

\subsection{Brezilya}

Güney Amerika'nın en kalabalık ve en büyük ülkesidir. Dünyanın yüzölçümü bakımından beşinci büyük ülkesidir. Güney Amerika'nın yarısı kadardır. GSYH açısından dünyanın dokuzuncu büyük ekonomisidir. 2016 yılında nüfusun \%14,06'sı kırsal alanda yaşarken $\% 86$ 'sı kentlerde yaşamaktadır.

Tablo 5. Brezilya'nın Ekonomik Göstergeleri

\begin{tabular}{|l|l|l|l|l|l|}
\hline Ylllar & $\mathbf{1 9 8 0}$ & $\mathbf{1 9 9 0}$ & $\mathbf{2 0 0 0}$ & $\mathbf{2 0 1 0}$ & $\mathbf{2 0 1 6}$ \\
\hline Nüfus (Milyar & 121.159 .761 & 149.352 .145 & 175.287 .587 & 196.796 .269 & 207.652 .865 \\
\hline $\begin{array}{l}\text { GSYİH } \\
\text { dolar) }\end{array}$ & 235 & 462 & 655,4 & 2.209 & 1.796 \\
\hline $\begin{array}{l}\text { Kişi Başına GSYïH } \\
\text { ABD Dolar }\end{array}$ & 1.939 & 3.093 & 3.739 & 11.224 & 8.649 \\
\hline İşsizlik Oranı & $4,26(1982)$ & 3,69 & 15,27 & 6,73 & $6,84(2015)$ \\
\hline Enflasyon Oranı & 87,30 & 2700 & 5,88 & 8,42 & 8,33 \\
\hline Büyüme Oranı & 9,11 & $-3,10$ & 4,11 & 7,52 & $-3,59$ \\
\hline
\end{tabular}

Kaynak: World Bank Data. https://data.worldbank.org/indicator, (Erişim Tarihi: 27.11.2017)

Zengin doğal kaynaklara sahip olmasl, demir, kömür, petrol, ranyum, platin ve metal ürünlerinde, tarım ürünleri (kahve, pamuk, şeker, portakal, kakao, tütün), canlı hayvan ürünleri(et, tavuk eti) ve orman ürünle- 
rinde (kağıt, kağıt hamuru) karşılaştırmalı üstünlüğe sahip olması, Brezilya'yı bu sektörlerde dünya sıralamasında birinci ya da ikinci sırada yer almasını sağlamaktadır (Özsoylu ve Algan, 2011, s.21).

İkinci Dünya Savaşından sonraki yıllarda ithal ikameci sanayileşme stratejisi uygulamıştır. 1965 yılından itibaren sanayi sektörünü çeşitlendirmesi ve gelişmesi ile hızla büyümüştür. Ancak korumacı politikaların içe dönük ve etkin olmayan bir ekonomiye yol açması nedeniyle 1970'lerin sonlarına doğru ithal ikameci strateji uygulaması çökmeye başlamıştır. Birbirini takip eden dış şoklar ve hızlı büyümeye karşın yüksek seyreden enflasyon, yatırımların azalmasına ve gelir dağılımının bozulmasına yol açmıştır. 1990'lı yıllarda Brezilya'da yaşanan liberilizasyon uygulamaları sonucunda özellikle otomotiv sektörü, altyapı gibi ekonominin belli sektörleri büyümüş ve modernizasyon gerçekleşmiştir. $\mathrm{Bu}$ aşamada yapılan özelleştirme ve yabancı yatırımlar etkili olmuştur (Özsoylu ve Algan, 2011, s.21).

Tablo: 6. Brezilya'da Sektörlerin GSYİH'ya Katkısı \%

\begin{tabular}{|l|l|l|l|l|l|l|l|l|}
\hline Yillar & $\mathbf{1 9 4 7}$ & $\mathbf{1 9 6 0}$ & $\mathbf{1 9 7 0}$ & $\mathbf{1 9 8 0}$ & $\mathbf{1 9 9 0}$ & $\mathbf{2 0 0 0}$ & $\mathbf{2 0 1 0}$ & $\mathbf{2 0 1 6}$ \\
\hline Tarım & 20,7 & 17,8 & 11,6 & 10,1 & 6,3 & 5,6 & 5,5 & 5,4 \\
\hline $\begin{array}{l}\text { Sanayi } \\
\text { İmalat } \\
\text { sanayi }\end{array}$ & 25,2 & 32,2 & 35,8 & 40,9 & 30,1 & 27,7 & 27,5 & 21,24 \\
\hline Hizmetler & 54,1 & 25,6 & 27,4 & 31,3 & 20,7 & 17,2 & 14,6 & 11,7 \\
\hline
\end{tabular}

Kaynak: (Nassif vd., 2013:9). https://data.worldbank.org/indicator/ NV.SRV. TETC. ZS?locations=BR (Erişim Tarihi: 27.11.2017)

1947'den 1980 yllına kadar Brezilya ekonomisi yıllık ortalama \%6,4 oranında büyümüş̧ür bu oran gelişmiş ve az gelişmiş ekonomilerin ortalamasının üzerinde bir orandır, İmalat sektörü yıllık ortalama \%8,6 oranında büyümüştür. 1970'ler boyunca sanayi sektörü yıllık ortalama \%7,4'e yakın büyüme gerçekleştirmiştir. Ülkenin sanayileşme sürecini tamamlaması açısından ithal ikameci strateji izlenmiştir. Ülkenin Birinci Kalkınma Planı (1968-1973) ile İkinci Kalkınma Planı (1974-1979) ülkenin üretken kapasitesinin artmasında önemli rol oynamıştır (Nassif vd., 2013, s.8). 


\subsection{Rusya}

Toprak büyüklügü bakımından 17.075.400 km2 ile dünya ülkeleri arasında birinci, nüfus açısından ise 144.342 .396 (2016) dokuzuncu sırada yer alan Rusya, sınırları içerisinde değişik milliyetlere mensup topluluklar bulunan bir devlettir. Dünya karasının \%12'sini oluşturur.

Kapitalist ekonomilerde sanayileşme genel olarak daha az yatırım fonu gerektiren ve ağır sanayiye göre daha hızlı sermaye rotasyonuna sahip olan ve daha kolay kâr elde edilebilmesini sağlayan hafif endüstrilerde başlamıştır. Bu ülkelerde endüstrileşmenin birinci amacı uzunca bir dönemde hafif endüstrilerin biriktirdikleri kârları bankalara yatırmaları ve böylece ağır endüstrilerin organizasyonunda gerekli koşulların oluşturulmasıdır. Ancak bu süreç çok uzundur. Bunun için onlarca yıl gerekmektedir. Hafif endüstrilerin ağır endüstri olmaksızın gelişmesi söz konusudur. Oysa Sovyetler Birliği mümkün olduğunca hızlı bir şekilde ağır endüstrileri geliştirmek istemiştir. Gerçekten de Stalin döneminde demir-çelik ve kömür temel endüstriler olmuştur. Ekonomik faaliyetlerin bir tek alanına yatırımların tahsis edilmesi çok büyük dengesizliklere neden olmuştur.

Sovyet planları beş yıllık planlar şeklinde değildi. Sovyet planları yıllıktı. Yıllık planlar beş yıllık planların hatalarını düzeltici etki yapmaktaydı ve ekonomiye sürekli müdahaleleri içeriyordu. Böylece bazı uzmanlara göre Sovyet ekonomisi öngörmelerden çok o sıradaki gereksinmelere göre yönetilen bir ekonomiydi (Başoğlu ve Parasız, 2002, s.30).

Rusya'nın GSYH içinde enerji sektörü etkin bir rol oynarken, federal bütçe fonlarının $\% 65^{\prime} \mathrm{i}$, ihracat gelirlerinin $\% 50$ 'den fazlası petrol ve gazdan elde edilmektedir. Rusya dünya enerji fiyatlarının yükselmesi ile adeta rant ekonomisinin getirisinden yararlanarak ekonomik krizler sonrası ekonominin toparlanmasında olumlu etki yaratmıştır. Enerji sektöründen sağlanan rantın \%25'den fazla olduğu tahmin edilmekte, petrol çıkarma ve doğal gazın kârlılığı, dünya fiyatlarından satışı diğer sektörlerin gerek girdi ithalinde gerekse ihracinda dişlama etkisi yaratmaktadır (Brunat ve Xavier, 2007, s.71). 


\subsection{Hindistan}

Asya'nın güneyinde Hint Okyanusuna doğru uzanan devasa bir yarımada konumunda olan Hindistan, dünyada nüfus büyüklüğü bakımından Çin'den sonra ikinci, yüzölçümü bakımından ise yedinci sıradadır. Yeryüzündeki toprakların \%2,3'üne sahiptir. GSYH açısından yedinci sırada yer almaktadır. Nüfusun \%67'si kırsal kesimde yaşamaktadır. Nüfusun \%6'sı 65 yaş üstü nüfusu oluşturmaktadır.

Tablo 7 Hindistan'ın Ekonomik Göstergeleri

\begin{tabular}{|l|l|l|l|l|l|}
\hline Yillar (mil- & $\mathbf{1 9 8 0}$ & $\mathbf{1 9 9 0}$ & $\mathbf{2 0 0 0}$ & $\mathbf{2 0 1 0}$ & $\mathbf{2 0 1 6}$ \\
\hline $\begin{array}{l}\text { Nüfus } \\
\text { yon) }\end{array}$ & 870 & 1.053 & 1.231 & 1.324 \\
\hline $\begin{array}{l}\text { GSYH (milyar } \\
\text { dolar) }\end{array}$ & 183 & 316 & 462 & 1.657 & 2.264 \\
\hline $\begin{array}{l}\text { Kişi Başına } \\
\text { GSYH }\end{array}$ & 263 & 363 & 438 & 1.345 & 1.709 \\
\hline Büyüme \% & 6,7 & 5,5 & 3,8 & 10,26 & 7,10 \\
\hline Enflasyon \% & 11,5 & 10,6 & 3,6 & 8,9 & 3,6 \\
\hline
\end{tabular}

Kaynak: https://data.worldbank.org/indicator/NV.SRV.TETC.ZS?locations=BR (Erişim Tarihi: 28.11.2017)

Tablo 8 Hindistan'ın Sektörel Dağılımı \%

\begin{tabular}{|l|l|l|l|l|l|}
\hline Ylllar & 1980 & 1990 & 2000 & 2010 & 2016 \\
\hline Tarim & 36,70 & 30,1 & 23,87 & 18,88 & 17,35 \\
\hline Sanayi & 28,99 & 31,63 & 31,04 & 32,42 & 28,84 \\
\hline Hizmetler & 34,29 & 38,26 & 45,08 & 48,69 & 53,80 \\
\hline
\end{tabular}

Kaynak:,https://data.worldbank.org/indicator/NV.SRV.TETC.ZS?locations=BR (Erişim Tarihi: 28.11.2017)

1950 ile 1957 yılları arasında liberal sanayi politikası izlenmiştir. Sonraki yıllarda sosyalist bir toplum modeline ulaşmak hedefiyle planlı ve hızlı ekonomik büyüme ile bu hedefe ulaşılacağını ekonomik ilerlemenin çerçevesi parlamenter demokrasi ve devletin önemli bir rol oynayacağ 1 karma ekonomik modeli çizildi. Hindistan'ın kendine yeterli ve beraberinde sosyal eşitliği getirecek bir ekonomik büyüme olarak belirlenen iktisadi kalkınma modeli izlenmeye başlandı. İkinci Beş Yıllık Kalkınma Planindan itibaren Mahalanobis modeli de denilen, amacı ekonomik büyümeyi artıracak şekilde yatırımların dört farklı üretim sektörü arasında dağıtılması olarak belirlenen model uyarınca kamu yatırımları 
neredeyse tamamı sermaye malları üretimine diğer bir deyişle ağır sanayiye ve altyapıya yoğunlaştırıldı. Bu model Birinci Beş Yıllık Kalkınma Planından farklı olarak merkezi planlamanın boyutunun genişletilmesini gerektiriyordu (Öz,2007, s.3).

Hindistan ekonomik açıdan, ucuz iş gücü imkânları, büyük bir pazar olması ve diğer olanaklarıyla yatırımcılar açısından dünyada en dikkat çekici ülkelerden biri konumuna ulaşmıştır.

İlk Kalkınma Planının (1951-1956) amacı, ekonomik büyümeyi sağlamak için iç tasarrufları artırmak ve ekonominin kolonik kurallardan ekonomiyi kurtarmaktır. Devletin girişimciliği sanayi sektörünün gelişmesine neden olmuştur. Ekonominin gelişimi ağırlıklı olarak kamu sektörüne verilmiştir. Sanayileşme politikasının amaçları; yüksek oranda büyüme,ulusun kendi kendine yeterli olması, yabancı hakimiyetin azaltılması, küçük boyuttaki sanayileri teşvik etmek, dengeli bölgesel kalkınma uygulamak, gelir eşitsizliğini azaltmak, devlet tarafından ekonominin kontrol edilmesidir (http://home.fau.edu/sghosh/web/images/India\%20-talk.pdf. Erişim Tarihi: 27.11.2017).

\section{TÜRKIYY'DE UYGULANAN KALKINMA POLITIIKALARI}

\subsection{Cumhuriyetten Günümüze Uygulanan Politikalar}

Cumhuriyet'in yüzyıla yaklaşan dönemi içinde kamu kesimi ile kalkınma çabaları genel olarak iki döneme ayrılabilir. İlk dönemlerde ekonominin kapasitesi de zorlanarak ciddi kalkınma hamleleri yapılmış, ekonomik büyüme yanında sosyal kalkınma ve gelişmeye özen gösterilmiştir. Kamu kesimi eliyle kıt kaynaklarla ekonomik işletmeler kurulmuş, önemli altyapı harcamalarında bulunularak, insani gelişmede önemli mesafeler alınmıştır. Dönemin ikinci yarısında ise kalkınma çabaları piyasaya terk edilmiş ve özel kesimin gelişimi ile kalkınmanın sağlanabileceği görüşü benimsenmiştir. Bu değişimin temel nedeni, ekonomik kalkınma ve gelişmenin gerçekleştirilmesiyle büyüyen sermayenin tercihlerinin kamusal tercihlerin önüne geçmesidir. Kalkınma çabalarının başarı ile yürütülmesinin iki önemli koşulu bulunmaktadır. Birincisi, kalkınma çabaları, özellikle de insan kaynaklı nitelikli kalkınma olgusu kamu kesimi eli ile daha etkili yürütülür. Bu nedenle kamu kesi- 
minin elinde bu amaca tahsis edilebilecek yeterince fon bulunmalıdir. İkincisi de gerek iç gerekse diş güçler siyasal otorite üzerinde piyasacı davranılması yönünde aşırı baskı oluşturabilecek güçte olmamalıdır. Bu iki ölçüte göre Türkiye'de kalkınma çabaları, özellikle de insani gelişme ölçütlerinin iyileştirilmesi açısından, Cumhuriyet'in ilk dönemleri ve devletçilik dönemleri, dönemin kıt imkânlarına karşın, oldukça olumludur. Buna karşın, örneğin 1980'ler ve özellikle de 2000'li yıllarda ekonomik istikrar ve büyümeye önem verilmiş, ekonomik kalkınma çabaları ise ikinci plana atılmıştır (Pınar, Önder, Gümüş., 2015, s.84).

Türkiye'de planlama anlayışı 1930'lu yıllarda hazırlanan sanayi planları ile başlamış, Devlet Planlama Teşkilatının kurulduğu tarihten günümüze kadar on adet Beş Yıllık Kalkınma Planı hazırlanmış ve uygulamaya konulmuştur. Literatürde genel kabul gören görüşe göre; planlarda birinci dönem, temel ekonomik perspektifler açısından Büyük Krizle başlayıp, İkinci Dünya Savaşının sonlarına kadar uygulanan devletçi politikalardan sonra, 1946-1958 yılları arasında özel sektöre öncelik veren 1960 öncesi dönemdir. İkinci dönem, ithal ikameci politikalarla birlikte kalkınmanın planlarla gerçekleşeceği düşünülen 19601980 dönemidir. Üçüncü dönem ise sanayileşme stratejisinde yapısal değişimin yaşandığı ve bu değişimin kalkınma planlarına yansıdığ 1980 sonrası dönemdir (Takım, 2011, s.155).

Ülkemizde 1930'larda başlayan plan yapma veya planlı kalkınma 1980 yılına kadar neredeyse aynı yöntem ve politikalarla ilerlemiştir. Planlarda ortak olan strateji karma ekonomi düzeni içinde ithal ikameci ya da sanayileşme stratejisidir.

Türkiye'nin hızlı kalkınmasında sanayi önemli bir yer tutmuştur. Sanayileşme açısından atılan önemli adımlardan biri de 28 Mayıs 1927 tarihli Teşvik-i Sanayi Kanunu'dur. Bu kanunun amaçları; milli sanayiyi özendirmek, yeni sanayi işletmelerinin açılmasını sağlamak, yerliyabancı büyük çaplı sanayi tesislerinin kurulmasını sağlamak ve Türk halkını birleştirerek toplu girişimlerde bulunmasını sağlamaktır. Bu nedenle de Kanun'da, parasız arazi temini, hammadde, makine ve teçhizata gümrük muafiyeti, çeşitli belediye vergi ve borçlarından muafiyet sağlanması gibi teşvikler getirilmesi öngörülmüştü. Teşvik-i Sanayi Kanunu'nun kabul edilmesinden sonra, özel girişim yoluyla hızlı sanayileşme konusundaki iyimser beklenti oldukça yükselmiş, sermaye 
çevrelerinde bir sevinç ve olumlu bir hava yaratmıştır. Nitekim Teşvik-i Sanayi Kanunu'nun kabul edilmesinden sonra kanundan yararlanan kuruluş sayısında da hızlı bir artış görülmüştür (Yakut v.d., 2015, s.69).

Tablo 9. 1923-1930 Yılları Arasında Türkiye'de Sektörlerin Milli Gelir İçindeki Payları

\begin{tabular}{|l|l|l|l|}
\hline Yillar & Tarim & Sanayi & Hizmetler \\
\hline 1923 & 43,3 & 13,4 & 43,3 \\
\hline 1924 & 48,1 & 11,9 & 40,0 \\
\hline 1925 & 45,0 & 12,8 & 42,2 \\
\hline 1926 & 50,3 & 12,0 & 37,7 \\
\hline 1927 & 40,0 & 16,9 & 43,1 \\
\hline 1928 & 42,8 & 15,6 & 41,6 \\
\hline 1929 & 50,1 & 13,9 & 36,0 \\
\hline 1930 & 47,1 & 14,9 & 38,0 \\
\hline
\end{tabular}

Kaynak: Parasız, 1998: 2

1923- 1930 yılları arasında milli gelir çok kararsız, inişli çıkışlı bir eğilim göstermektedir. Bu durum büyük ölçüde tarımsal üretimdeki değişmelerden kaynaklanmaktadır; tarımsal ürün fiyatlarında iç ve dış piyasa koşullarına göre meydana gelen dalgalanmalar ve tarımının büyük ölçüde hava koşullarına bağlı olmasıyla açılanabilir. 1929-1930 döneminde tarımsal üretimin durumu diğer sektörlerdeki gelişmeleri belirleyici niteliktedir. Tarımsal üretimin iyi olması diğer sektörlerde de üretimin artmasına neden olmaktadır. Tarımsal gelirin toplam katkılı gelir içindeki oranı \%40-50 civarındadır. Tarımın ardından ikinci sırayı hizmetler sektörü almaktadır (Parasız, 1998, s.1).

1930'lu yıllarda Türkiye'de izlenen devletçilik politikalarının biçimlenmesinde şu etmenler etkili olmuştur: Birincisi; 1923-1929 yılları arasında izlenen liberal iktisat politikalarından fazla başarılı sonuç elde edilmemesi, İkincisi; 1929 Ekonomik krizinin tüm dünya ekonomilerini olumsuz yönde etkilemesi, üçüncüsü Sovyetler Birliğinde uygulanmakta olan planlı iktisat politikalarının ilk sonuçlarının başarılı olması, Batı ülkelerinde klasik iktisat politikalarının 1929 krizine çözüm getirememesi üzerine Devletin ekonomiye müdahale etmesini savunan görüşlerin ortaya atılmaya başlanması ve bu yönde iktisat politikaları izlenmeye başlanmasıdır (Parasız,1998, s.29).

1930'larda uygulamaya koyulmuş olan devletçilik politikalarını sadece ekonomik yapılanma ve büyüme aşaması olarak görmek yanlış 
olur. 1930'lar döneminde, 1923-1929 liberal dönemdekinden farklı olarak, sosyal kalkınma çabalarının da yoğun olduğu görülmektedir. Devletçilik uygulamaları ile ülkenin çeşitli yerlerine kurulmuş olan kamu iktisadi teşebbüsleri sadece üretim birimleri olma işlevini görmemiş, etraflarındaki sosyal tesisleri ile toplumsal kalkınmada da öncülük görevi yüklenmiştir. Kamu iktisadi teşebbüslerinin kuruluş yerlerinin seçiminde de ekonomik kârlılık ölçütünden çok, sosyal getiri ve yöresel kalkınmanın sağlanması çabaları esas alınmıştır. Böylece, bu dönemde ekonomik büyümeye paralel olarak sosyal kalkınmanın gerçekleştirilmesinde de önemli adımlar atılmıştır (Pınar, Önder ve Gümüş, 2015, s.71).

1950-1960 yılları arasında liberal ekonomi politikaların benimsenmesiyle, devletin ekonomik hayattaki etkinliğini sınırlandırma amacına uygun olarak, kalkınma için plan yapma yoluna gidilmemiştir. 1950'li yılların sonlarına doğru ekonomik göstergelerdeki bozulmalar, dış kaynak sağlayan kuruluşların da etkisiyle, kalkınmanın plan dahilinde yürütülmesi gerekliliğini ortaya çıkarmıştır (Takım, 2011, s.156).

1960'li yıllarda büyük bir yatırım hamlesi olarak planlar aynı zamanda vergilerin, iç ve dış borçlanmanın artmasına neden olmuş yani finansman gerektirmiştir. Planların ilk yıllarında büyük oranda iç borçlanma ile yürütülen yatırımlar ikinci ve üçüncü plan dönemlerinde yoğun olarak dış borçlanmaya bağlıdır. İlk üç planlı dönem boyunca \%7'lik büyüme oranının neredeyse yakalanmış olma nedeni ekonomide önemli boyutlardaki dış kaynaktandır (Yakut v.d., 2015, s.191).

Türkiye 1963'den bu yana kalkınma planlarıyla yönetilmiş, ithal ikameci sanayileşme stratejisinin ilk aşaması olarak nitelendirilen temel tüketim mallarının ülke içerisinde üretimi 1960'ların ortalarına kadar tamamlanmıştır. Planlı dönemle birlikte ithal ikamesinin ikinci aşaması başlamış fakat ikinci aşama olan ara ve yatırım malları üretimine tam anlamıyla geçilememiştir. Tikanma noktasına gelen ekonomiyle bu ithal ikameci stratejiden vazgeçilip 24 Ocak 1980 Kararları ile ihracata dönük kalkınma stratejisine geçilmiştir. 24 Ocak kararları, Türkiye açısından bir dönüm noktası olmuştur. Bununla iç piyasada istikrar ve dış ödemelerde dengeyi sağlamak amaçlanıyordu. Bu amaca ulaşmak için, hükümet iç piyasayı olabildiğince serbest bırakmak, fiyat kontrollerini kaldırmak, dış ticareti liberalleştirmek ve büyük oranlı devalüasyonlara 
başvurmuştur. İhracata dönük kalkınma stratejisinin izlenmesinin ikinci nedeni ise; ülke içerisinde gelişen sanayi kesiminin dışa açılma isteğidir. İran Irak savaşı ve Orta Doğu'daki petrol zengini ülkelerin yarattığı talebin çekiciliğiyle dişa açılmanın gerekliliği ileri sürülmüş ve gerekli kurumsal ve ekonomik altyapının oluşturulması istenmiştir. Diğer dışa açılma gerekçesi ise, IMF, OECD ve OPEC gibi uluslararası kuruluşların baskısını hafifletmek ve bu kuruluşlardan dış ödemeler için yardım alınmak istenmesidir (Dağdemir v.d., 2015, s.94-95).

Türkiye'de 1980 öncesi ekonomik yapının temel özelliği, kamunun öncülügünde yürütülen ithal ikameci sanayileşme politikasıdır. Bu politika ile, yurt içi talebe yönelik olarak yapılan üretimle büyüme sağlanacak ve kamu yatırımları ile bu süreç desteklenecektir. Bu politika, İkinci Dünya Savaşı sonrasında birçok ülkede olduğu gibi, Türkiye'de de 1963 yılında başlanan planlı kalkınmanın vazgeçilmez bir parçası idi. Ancak bu tür bir politikanın çeşitli nedenlerle uluslararası ekonomik yapı içerisinde başarısız olma riski söz konusudur. Birinci neden, yurt içi talebe yönelik üretim yapıldığından, büyümenin sürdürülebilmesi için, tüketici kitlelerin gelirinin yüksek olması gerekir. Bu yüzden de yüksek düzeyde seyreden ücretler, aynı zamanda bir maliyet unsuru olduğundan enflasyonu körükler. İkinci neden, üretim sürecinde kullanılan girdilerin bir kısmı dışarıdan satın alındığı için, dövize ihtiyaç vardır. Türkiye bu ihtiyacı bir süre yurt dişında çalışan işçi dövizlerinden karşılamış fakat bu döviz kazancı azaldığında, sürekli borçlanma yapılamayacağına göre, döviz darboğazına girmiş ve ödemeler dengesi sorunları ortaya çıkmıştır. Üçüncü neden, yurt içi tüketim ile desteklenen bu büyüme stratejisinde, yatırımları teşvik edecek tasarruflar yetersiz kalabilir. Bu yüzden, yatırımların bir bölümü yüksek vergilerle yaratılan kamu tasarrufları ile finanse edilirken, özel sektör yatırımları yetersiz kalabilir ve dolayısıyla artan iş gücü için yeterli istihdam yaratılamaz. Dördüncü neden, dışa kapalı ekonomilerde bir süre mümkün olan bu stratejinin temel sorunlarından birisi de rekabetçi olmayan bir ekonomik yapıda, verimlilik ve kalite sorunu ortaya çıkarmasıdır. Daha kaliteli ve daha ucuza mal üreten ülkelerle rekabet edemeyen ekonomilerde ise bir süre sonra bu kalkınma stratejisi başarısız olur (Pınar, Önder, Gümüş., 2015, s.4). 
1962-1980 yılları planlı kalkınmanın gelişme dönemi denilen bu dönemde dört kalkınma planı hazırlanmıştır. Bunların ortak özellikleri şunlardır: Ekonomik ve toplumsal yapıyı veri almaları, ekonomik büyümeyi ve bunun yıllık artış oranını temel belirleyici değişken olarak almaları, sanayileşmeye öncelik vermeleri, uzun dönemli planlama ihtiyacını karşılamak üzere uzun süreli gelişme stratejileri hazırlamalarıdır (Özdemir, 2013, s.12).

İnsan hak ve hürriyetlerini, milli dayanışmayı, sosyal adaleti, ferdin ve toplumun huzur ve refahını gerçekleştirmeyi ve teminat altına almayı mümkün kılacak bir demokratik düzeni kabul etmiş olan Türk Milletinin, 1961 Anayasasında açık ifadesini bulan iktisadi ve sosyal hayatı, keyfi ve plansız davranış tecrübelerine son verip adalete, tam çalışma esasına ve herkesin insan haysiyetine yaraşır bir yaşayış seviyesi sağlanmak amaciyla düzenleme arzu ve azmine uygun olarak: Milli tasarrufu artırmak, yatırımları toplum yararına, gerektirdiği önceliklerle yöneltmek ve iktisadi, sosyal ve kültürel kalkınmayı demokratik yollarla gerçekleştirmek üzere Birinci Beş Yıllık (1963 - 1967) Kalkınma Planı hazırlanmıştır denilmektedir (http://ekutup.dpt.gov.tr/plan1.pdf," s.3). Plan ayrıca, ekonomik büyüme hedefleri yanında, ödemeler dengesinin gözetilmesi, gelir dağılımın düzeltilmesi, vergi reformunun yapılması gibi amaçlar yanında, nüfus politikası ve sosyal adaletin sağlanması gibi sosyo-ekonomik sorunlara da el atmış, böylece ekonomik veriler üzerinde değil, sosyal verilerde de etkin toplumsal dönüşümler oluşturmayı hedeflemiştir (Pınar, Önder ve Gümüş., 2015, s.73).

Yeni perspektife göre hazırlanan III. Beş Yıllık Kalkınma Planı, gelir seviyesinin arttırılmasını, sanayileşmenin özellikle ara ve yatırım malı üreten sektörlerde hızlandırılmasını ve dış kaynaklara bağımlılığın azaltılmasını amaçlamıştır.

Dördüncü plan (1979-1983), büyük bir ekonomik ve siyasal bunalım dönemine denk gelmiş ve bu nedenle de bir yıl gecikmeyle uygulamaya koyulmuştur. Ekonomik bunalımın sebebi daha öncekilerle aynıdır fakat bu sefer çok daha ağır olan dış borç ve yüksek oranlı enflasyonla karşımıza çıkmıştır. Dördüncü Beş Yıllık Kalkınma Planında tarımın büyüme hızı diğer planlara göre daha yüksek tutulmuş sanayinin büyüme hızı ise önceki yıllara göre düşük öngörülmüştür. Bunun sebebi o yıllardaki ekonomik krizin daha çok sanayi kesimini etkilemesidir. 
Tablo 10. Plan Dönemleri İtibarıyla Hedeflenen ve Gerçekleşen Yıllık Ortalama Büyüme Oranları

\begin{tabular}{|l|l|l|}
\hline Planlama Dönemleri & Hedef & Gerçekleşme \\
\hline Birinci Plan Dönemi (1963-1967) & $\% 7,0$ & $\% 6,6$ \\
\hline İkinci Plan Dönemi (1968-1972) & $\% 7,0$ & $\% 6,3$ \\
\hline Üçüncü Plan Dönemi (1973-1978) & $\% 7,9$ & $\% 5,2$ \\
\hline Dördüncü Plan Dönemi (1979-1983) & $\% 8,0$ & $\% 1,7$ \\
\hline Beşinci Plan Dönemi (1985-1989) & $\% 6,3$ & $\% 4,7$ \\
\hline Altınci Plan Dönemi (1990-1994) & $\% 7,0$ & $\% 3,5$ \\
\hline
\end{tabular}

Kaynak: Pınar vd. 2015, s.73

Tablo 10'da görüldügü gibi dört plan dönemi süresince yıllık büyüme hedefi ortalaması \% 7,4, buna karşılık gerçekleşme ortalaması ise \% 4,9'dur. Bu durumda dönem boyunca hedefin ancak yarısı gerçekleştirilebilmiştir. Diğer bir deyişle, planlama ile saptanan hedeflerin ekonomik kalkınmanın arzulanan düzeyde gerçekleşmesinin ön koşulu olarak kabul edilmesi durumunda, kalkınma aşamasında yeterli mesafenin alınamamış olduğu sonucuna varılmaktadır.

1980 sonrası uygulanan ekonomi politikası geçmiş dönemlerdekinden hayli farklıdır. Farklılık, ekonominin ihracata yönelik liberal ve monetarist politikalara yönelmesindedir. Bu farklılığın da içten ve dıştan kaynaklanan nedenleri bulunmaktadır. İlk olarak, 1960'lar ve 70'lerde uygulanmış olan ithal ikameci ve korumacı politikalar sonucunda ekonomi döviz darboğazına girmiş böylece ekonomi, ilki 1929'da, ikincisi de 1958'de yaşanan döviz darboğazına 1979 yılında üçüncü kez sürüklenmiştir. Dış dünya ile ilgili neden ise kapitalist dünyada 1970'lerin ortalarından itibaren reel sektörde kâr oranlarının gerilemesine bağlı olarak finansal alana geçilmesi ve reel yatırım alanlarına yönelmede istekli olmayan birikmiş fonların kendilerine yüksek getiri sağlayan alanlar arıyor olmasıdır (Pınar, Önder veGümüş, 2015, s.75).

2000 yılında uygulamaya konulan ve günümüze dek uygulanan IMF istikrar programı ve Güçlü Ekonomiye Geçiş Programı ise ekonomik kalkınma ve sosyal amaçtan uzaktır. Bu projelerin hedefi, ekonomik istikrarın sağlanması, enflasyonun baskılanması ve borç yönetim sisteminin oluşturulması idi. Bu durumda ister istemez ekonomik kalkınma ve sosyal projeler arka plana atılmış ve ekonomik istikrar ön plana çıkmış- 
tır. Ekonomik büyüme sağlanıp, kişi başına gelir yükseldikçe, kendi doğal sürecinde, nispi olarak ekonomik kalkınma da gerçekleşmekte ve İnsani Gelişme Göstergeleri de iyileşmektedir. Ancak ülkemizde ekonomik büyüklük olarak önümüzdeki ylllarda ilk on arasına girmeye çal1şırken, ekonomik kalkınma ve insani değerler göstergelerinde daha üst sıralara yükselme hedefinin toplumun ve politikanın gündeminde olduğu söylenememektedir (Pınar, Önder ve Gümüş., 2015, s.82).

Hızlı bir ekonomik kalkınma için ülkenin daha fazla yatırımlara ihtiyacı vardır bunu gerçekleştirmek içinde tasarrufların olması gerekir. İktisat mantığına göre yatırımlar tasarruflara eşit olması gerekir. Türkiye'de ekonomik kalkınmayı hızlandırabilmek için gerekli olan yatırımların artırılmasında en önemli sıkıntı yurtiçi tasarrufların arttırılamamasıdir.

Tablo 11.Türkiye'nin ve Bazı Ülkelerin Tasarruflarıın GSYH'ye Oranı

\begin{tabular}{|l|c|c|c|c|c|}
\hline Ylllar & $\mathbf{1 9 8 0}$ & $\mathbf{1 9 9 0}$ & $\mathbf{2 0 0 0}$ & $\mathbf{2 0 1 0}$ & $\mathbf{2 0 1 6}$ \\
\hline Türkiye & 12,90 & 21,56 & 20,98 & 21,32 & 24,5 \\
\hline Çin & $35,50(1982)$ & 38,44 & 36,45 & 51,49 & 46,05 \\
\hline Brezilya & 17,86 & 18,92 & 12,51 & 17,95 & 13,87 \\
\hline Rusya & & $29,57(1994)$ & 36,15 & 27,18 & 25,36 \\
\hline Hindistan & 20,27 & 27,16 & 27,94 & 38,23 & 30,17 \\
\hline
\end{tabular}

Kaynak: Gross savings (\% of GDP), https://data.worldbank.org/indicator/NY.GNS.ICTR.ZS

Tablo 12. Türkiye'nin Yatırım Tasarruf Dengesi (GSYH'ye göre oranı)

\begin{tabular}{|l|c|c|}
\hline Yillar & 2016 & $\begin{array}{c}2017 \text { (Gerçekleşme } \\
\text { Tahmini) }\end{array}$ \\
\hline Toplam Tüketim & 74,7 & 74,1 \\
Kamu & 11,0 & 10,7 \\
Özel & 63,7 & 63,5 \\
\hline Toplam Yatırım & 28,2 & 29,5 \\
Kamu & 4,1 & 4,2 \\
Özel & 25,3 & 26,4 \\
\hline Stok Değişmesi & $-1,1$ & $-1,1$ \\
\hline Toplam Yurtiçi Tasarruf & 24,5 & 25,0 \\
Kamu & 2,7 & 1,6 \\
Özel & 21,7 & 23,3 \\
\hline Toplam Yatırım Tasarruf fark1 & $-3,7$ & $-4,5$ \\
\hline
\end{tabular}

Kaynak: 2018 yılı Programı Erişim Tarihi: 06.02.2018) 
Türkiye'de yatırım tasarruf dengesine baktığımızda 2016 ve 2017 yıllarında tasarruf açığı vermiştir. Toplam yatırımların GSYH'ye oranı 2016 yılında \%28,2 olarak gerçekleşmiş bunun \%4,1 kamu tarafından \%25,3 ise özel kesim tarafından gerçekleştirilmiştir. Yurtiçi tasarruflara baktığımızda GSYH'ye oranı \%24,5'dir. Kamunun tasarrufu \%2,7 özel kesimin tasarrufu \%21,7'dir. 2016 yılında \%3,7 oranında tasarruf açığ gerçekleşmiştir. Toplam tüketimin GSYH'ye oranı \%74,7'dir, bunun \%11,0'i kamu \%63,7'si özel kesim tarafından gerçekleştirilmiştir.

Tablo 13. Türkiye'nin İlgili Yillara Göre Program Hedefleri

\begin{tabular}{|l|l|l|l|l|}
\hline Yillar & $\begin{array}{l}\mathbf{2 0 1 4} \text { Progra- } \\
\mathbf{m i}\end{array}$ & $\begin{array}{l}\mathbf{2 0 1 5} \text { Prog- } \\
\text { rami }\end{array}$ & $\begin{array}{l}\mathbf{2 0 1 6} \text { Prog- } \\
\text { ramı }\end{array}$ & 2017 Programı \\
\hline GSYH (ABD Milyar Dolar) & 867.3 & 850.1 & 735.6 & 756.3 \\
\hline Ekonomik Büyüme & 4,0 & 4,0 & 4,5 & 4,4 \\
\hline $\begin{array}{l}\text { Kişi Başına GSYH (ABD } \\
\text { Doları) }\end{array}$ & 11.277 & 10.936 & 9.364 & 9.529 \\
\hline İşsizlik Oranı & 9,4 & 9,5 & 10,2 & 10,2 \\
\hline Enflasyon Oranı TÜFE & 5,3 & 6,3 & 7,5 & 6,5 \\
\hline Cari İşlemler Dengesi/GSYH & $-6,4$ & $-5,4$ & $-3,9$ & $-4,2$ \\
\hline $\begin{array}{l}\text { AB Tanıml Devlet Nominal } \\
\text { Borç Stoku/GSYH }\end{array}$ & 33,0 & 31,8 & 31,7 & 31,9 \\
\hline İşücüne Katılma Oranı & 51,3 & 50,2 & 51,7 & 52,3 \\
\hline
\end{tabular}

Kaynak: Kalkınma Bakanlı̆̆ı

Tablo 14. Türkiye'nin İlgili Yıllara Göre Gerçekleşme Rakamları

\begin{tabular}{|l|l|l|l|l|}
\hline Yillar & 2014 & 2015 & 2016 & $\begin{array}{l}\text { 2017 Gerçekleşme } \\
\text { Tahmini) }\end{array}$ \\
\hline GSYH (ABD Milyar Dolar) & 935 & 862 & 863 & 847 \\
\hline Ekonomik Büyüme & 5,2 & 6,1 & 3,2 & 5,5 \\
\hline $\begin{array}{l}\text { Kişi Başına GSYH (ABD Dola- } \\
\text { r1) }\end{array}$ & 12.112 & 11.019 & 10.883 & 10.579 \\
\hline İşsizlik Oranı & 9,9 & 10,3 & 10,9 & 10,8 \\
\hline Enflasyon Oranı TÜFE & 8,2 & 8,8 & 8,5 & 9,5 \\
\hline Cari İşlemler Dengesi/GSYH & $-4,7$ & $-3,7$ & $-3,8$ & $-4,6$ \\
\hline $\begin{array}{l}\text { AB Tanımlı Devlet Nominal } \\
\text { Borç Stoku/GSYH }\end{array}$ & 28,6 & 27,5 & 28,1 & 28,5 \\
\hline İşücüne Katılma Oranı & 50,5 & 51,3 & 52,0 & 52,7 \\
\hline
\end{tabular}

Kaynak: Kalkınma Bakanlığı

Yukarıda Tablo 14'de görüldüğü gibi dört yılın ekonomik büyüme program hedefleri sadece 2016 yılında gerçekleşen oran, programın altında kalmıştır. İşsizlik oranı gerçekleşen oranla program hedefi aşağı 
yukarı tutmuştur. Enflasyon oranı gerçekleşen ile program oranı tutmamıştır. Tahmin edilen oranın üzerinde gerçekleşmiştir. Cari işlemler dengesi/GSYH'a oranı program hedefinin birazcık altında gerçekleşmiştir. AB Tanımlı Devlet Nominal Borç Stoku/GSYH'e oranı program hedefinin altında gerçekleşmiştir. İşgücüne Katılma Oranı program hedeflerinin birazcık üstünde gerçekleşmiştir. Sonuç itibariyle tabloda verilen dört yılın ekonomik göstergelerinden hedeflerin tutturulduğu sadece enflasyon hedefinde sapmanın olduğu görülmektedir.

Tablo 15. Türkiye'nin Daha İyi Yaşam Endeksi Göstergeleri

\begin{tabular}{|l|l|l|l|l|l|l|}
\hline & Konut & Gelir & İş & Toplum & Eğitim & Çevre \\
\hline $\begin{array}{l}\text { Türkiye (38 } \\
\text { Ülke) sırası }\end{array}$ & 29 & 34 & 35 & 33 & 35 & 37 \\
\hline $\begin{array}{l}\text { Maksimum } \\
\text { Puan }\end{array}$ & 8,7 & 10,0 & 9,5 & 10,0 & 8,7 & 10,0 \\
\hline Türkiye'nin Puanı & 5,2 & 1,0 & 4,5 & 4,3 & 2,6 & 2,6 \\
\hline Minimum Puan & 2,5 & 0,3 & 0,2 & 0,0 & 0,6 & 2,5 \\
\hline & $\begin{array}{l}\text { Sivil } \\
\text { Katılım }\end{array}$ & Sağlık & $\begin{array}{l}\text { Yaşam } \\
\text { emnuniyeti }\end{array}$ & Güven & $\begin{array}{l}\text { İş- } \\
\text { Yaşam } \\
\text { Dengesi }\end{array}$ & \\
\hline $\begin{array}{l}\text { Türkiye (38 } \\
\text { Ülke) sırası }\end{array}$ & 6 & 24 & 34 & 30 & 38 & \\
\hline $\begin{array}{l}\text { Maksimum } \\
\text { Puan }\end{array}$ & 8,6 & 9,6 & 10,0 & 9,9 & 9,3 & \\
\hline Türkiye'nin Puanı & 6,7 & 6,9 & 2,4 & 7,1 & 0,0 & \\
\hline Minimum Puan & 1,3 & 3,1 & 0,0 & 0,1 & 0,0 & \\
\hline
\end{tabular}

Kaynak:http://www.oecdbetterlifeindex.org/\#/11111111111(Erișim Tarihi:30.01.2018).

Tablo 15 incelendiğinde OECD tarafından hazırlanan 2017 daha iyi yaşam endeksine göre 38 ülke içerisinde 11 alanda Türkiye'nin son sıralarda yer aldığ görülmektedir. Türkiye sadece sivil katılım alanında 6 . sırada diğer alanlarda son sıralarda yer almaktadır. 
Tablo 16.Türkiye'nin 2017 Legatum Prosperty Indeksine Göre 149 Ülke İçerisindeki Stralaması

\begin{tabular}{|l|l|}
\hline BİLEŞEN & SIRALAMA \\
\hline Ekonomik Kalite & 55 \\
\hline İş Çevresi & 91 \\
\hline Hükümet-Yönetim & 70 \\
\hline Eğitim & 80 \\
\hline Sağllk & 53 \\
\hline Güven-Güvenlik & 133 \\
\hline Kişisel Özgürlük & 105 \\
\hline Sosyal Sermaye & 96 \\
\hline Doğal çevre & 54 \\
\hline
\end{tabular}

Kaynak: http://www.prosperity.com/globe/Norway, (Erişim Tarihi:30.01.2018).

2017 Legatum Prosperty Endeksine göre Türkiye 149 ülke arasında 88. Sırada yer almaktadır. 2016 yılında Türkiye 78. Sırada iken 2017'de 10 ülke daha Türkiye'yi geçmiştir.

Tablo 17. Türkiye'nin Bazı Ülkelerle 2017 Legatum Prosperty İndeksine göre Karşılaştırılması

\begin{tabular}{|l|l|l|}
\hline ÜLKE & $\mathbf{2 0 1 7}$ Yilında sirasi & $\mathbf{2 0 1 6}$ Yilında sırasi \\
\hline Türkiye & 88 & 78 \\
\hline Çin & 90 & 90 \\
\hline Rusya & 101 & 95 \\
\hline Brezilya & 54 & 52 \\
\hline Hindistan & 100 & 104 \\
\hline
\end{tabular}

Kaynak:

http://prosperitysite.s3accelerate.amazonaws.com/3515/1187/1128/Legatum_Prosperity_Index_ 2017.pdf , (Erişim Tarihi:30.01.2018).

Yukarıdaki Tablo 17 incelendiğinde Çin 2017'de sıralamasını korurken, Türkiye, Rusya ve Brezilya 2016 yılındaki sıralamasına göre geri sıralara düşmüşlerdir. Hindistan ise 104. Sıradan 100. Sıraya yükselmiştir.

Tablo: 18. Türkiye'nin GSYİH Bakımından Dünyadaki Yeri (2016)

\begin{tabular}{|l|l|l|}
\hline Sira & Ülke & GSYİH (Milyon Dolar) \\
\hline 1 & ABD & 18.624 .475 \\
\hline 2 & Çin & 11.199 .145 \\
\hline 7 & Hindistan & 2.263 .792 \\
\hline 9 & Brezilya & 1.796 .187 \\
\hline 12 & Rusya & 1.283 .163 \\
\hline 17 & Türkiye & 863.712 \\
\hline
\end{tabular}

Kaynak:https://data.worldbank.org/data-catalog/gdp-ranking-table(ErişimTarihi: 31.01.2018). 
Karşılaştırdığımız ülkeler arasında Türkiye GSYİH açısından en son siradadir.

Tablo 19.Türkiye ve Bazı Ülkelerin İşsizlik Oranlarııın Karşılaştırılması (2017 yılı)

\begin{tabular}{|l|l|}
\hline Ülke Ad1 & 2017 yıl işsizlik oranı \\
\hline Türkiye & 11,4 \\
\hline Çin & 4,6 \\
\hline Rusya & 5,3 \\
\hline Brezilya & 13,4 \\
\hline Hindistan & 3,6 \\
\hline
\end{tabular}

Kaynak: https://data.worldbank.org/indicator/SL.UEM.TOTL.ZS (Erişim Tarihi: 08.02.2018).

Türkiye ve diğer tablodaki ülkelerin işsizlik rakamlarına baktığımızda; en kötü durumda olan ülke Brezilya diğer durumu kötü olan ülke Türkiye' dir. Diğer ülkelerin işsizlik oranları daha iyi durumdadır.

Tablo 20. Dünya Bankasının 2012 Yılında Yapmış Olduğu Kişi Başına Düşen Gelire Göre Ülkelerin Sinıflandıriması

\begin{tabular}{|l|l|}
\hline $\begin{array}{l}\text { Düşük Gelirli Ülke- } \\
\text { ler }\end{array}$ & Kişi başına 1.005 dolar ve daha az GSMH'ya sahip ülkeler \\
\hline Orta Gelirli Ülkeler & $\begin{array}{l}\text { Kişi başına 1.006 dolar ile 12.275 dolar arasında GSMH'ya } \\
\text { sahip ülkeler. Bu grup oldukça geniş olacağından iki alt } \\
\text { gruba ayrılmıştır. } \\
\text { Kişi başına düşen gelir 1.006- 3.975 dolar olanlar düşük orta } \\
\text { gelirli ülke ve kişi başına düşen gelir 3.976-12.275 dolar olan- } \\
\text { lar ise yüksek orta gelirli ülkelerdir. }\end{array}$ \\
\hline $\begin{array}{l}\text { Yüksek Gelirli Ülke- } \\
\text { ler }\end{array}$ & $\begin{array}{l}\text { Kişi başına 12.276 dolardan daha fazla GSMH'ya sahip olan } \\
\text { ülkeler de yüksek gelirli ülkeler olarak adlandırılmaktadır. }\end{array}$ \\
\hline
\end{tabular}

Kaynak: Erden, vd. 2013, 14.

Tablo 21. Türkiye ve Bazı Ülkelerin Cari Fiyatlara Göre Kişi Başına Düşen GSYH (2016) Amerikan Dolar

\begin{tabular}{|l|l|}
\hline Ülke & Kişi Başına Düşen GSYH (ABD Dolari) 2016 \\
\hline Lüksemburg & 100.573 \\
\hline Türkiye & 10.862 \\
\hline Rusya & 8.748 \\
\hline Brezilya & 8.649 \\
\hline Çin & 8.123 \\
\hline Hindistan & 1.709 \\
\hline
\end{tabular}

Kaynak: https://data.worldbank.org/indicator/NY.GDP.PCAP.CD (Erişim Tarihi:31.01.2018). 
Dünya Bankasının 2012 yılında yapmış olduğu gelir sınıflandırmasına göre Hindistan düşük orta gelirli ülke grubunda iken Türkiye, Rusya, Brezilya, Çin yüksek orta gelirli ülke grubunda yer almaktadır.

Tablo 22. Türkiye'nin Yıllar Itibariyle Sektörlerin GSYH İçindeki Paylar

\begin{tabular}{|l|l|l|l|l|l|l|l|}
\hline SEKTÖR & 1960 & 1970 & 1980 & 1990 & 2000 & 2010 & 2016 \\
\hline Tarım & 55,98 & 40,16 & 26,50 & 18,09 & 11,25 & 10,26 & 7,0 \\
\hline Sanayi & 17,66 & 22,54 & 23,81 & 32,15 & 30,04 & 27,98 & 31,97 \\
\hline Hizmetler & 26,49 & 37,29 & 49,68 & 49,75 & 58,69 & 61,75 & 61,00 \\
\hline
\end{tabular}

Kaynak:https://data.worldbank.org/indicator/NV.SRV.TETC.ZS?locations=TR (Erişim Tarihi:31.01.2018)

Tablo 23. Türkiye'nin Sektörlere Göre İhracatı

\begin{tabular}{|l|l|l|l|l|l|l|}
\hline & \multicolumn{3}{l}{ Milyar ABD Doları } & \multicolumn{2}{l|}{ Yüzde pay } \\
\hline Y1l & 2015 & 2016 & 2017 & 2015 & 2016 & 2017 \\
\hline Toplam İhracat & 143.8 & 142.5 & 157.0 & 100,0 & 100,0 & 100,0 \\
\hline Tarım ve Ormancılık & 5.8 & 5.4 & 5.2 & 4,0 & 3,8 & 3,4 \\
\hline Balıkçılık & 0.4 & 0.4 & 0.4 & 0,3 & 0,3 & 0,3 \\
\hline Maden ve Taş Ocakçılı̆̆1 & 2.8 & 2.7 & 3.5 & 1,9 & 1,9 & 2,2 \\
\hline İmalat & 134.4 & 133.6 & 147.2 & 93,4 & 93,7 & 93,7 \\
\hline Diğger & 0.5 & 0.4 & 0.6 & 0,4 & 0,3 & 0,4 \\
\hline
\end{tabular}

Kaynak: TüIKK

Tablo 24. Türkiye'nin Sektörlere Göre İthalatı

\begin{tabular}{|l|l|l|l|l|l|l|}
\hline \multicolumn{4}{|l|}{ Milyar ABD Doları } & Yüzde pay \\
\hline Y1l & 2015 & 2016 & 2017 & 2015 & 2016 & 2017 \\
\hline Toplam İthalat & 207.2 & 198.6 & 233.8 & 100,0 & 100,0 & 100,0 \\
\hline Sermaye Malları & 34.9 & 35.9 & 33.1 & 16,8 & 18,1 & 14,2 \\
\hline Ara malları & 143.3 & 134.3 & 171.5 & 69,2 & 67,6 & 73,3 \\
\hline Tüketim Malları & 28.6 & 27.9 & 28.5 & 13,8 & 14,1 & 12,2 \\
\hline Diğger & 0.4 & 0.4 & 0.7 & 0,2 & 0,2 & 0,3 \\
\hline
\end{tabular}

Kaynak: TüIKK

Türkiye'nin dış ticaret yapısına baktığımızda ithalatı ihracatından fazla olduğunu görmekteyiz. Bu açık ya borçlanmayla ya da ülke rezervleriyle karşılanır. Bu durum ülke kalkınması açısından olumsuz bir durumdur. İhracatta imalat sanayi ürünlerinin payı \%94'lere yakındır. İthalat yapısına bakacak olursak, ara mallarının payı \%73'lerde sermaye mallarının payı \%14'lerdedir. İthalat ara mallarının payını düşürmek için bu malların üretimini yurtiçinde yapılması için teşvik edilmesi gerekir. 
Türkiye ara malları üretiminde ithal ikameci politika izleyerek ithal ettiği ara mallarını yurtiçinde üretmeyi başarırsa döviz tasarrufu sağlayacak ve cari açık sorunu azalacaktır. Bu kaynak fazlalığını başka alanlarda kullanabilecek ya da dış borçlarını ödeyecektir.

Tablo 25 Türkiye'nin İhracatta Teknoloji Yoğunluğuna Göre İmalat Sanayi Ürünleri

\begin{tabular}{|c|c|c|c|c|c|c|}
\hline & \multicolumn{3}{|c|}{$\begin{array}{l}\text { Toplam İmalat Sanayi Tutarı } \\
\text { Milyar ABD Doları }\end{array}$} & \multicolumn{3}{|c|}{ Yüzde pay } \\
\hline Yil & 2015 & 2016 & 2017 & 2015 & 2016 & 2017 \\
\hline Toplam İmalat Sanayi & 134.4 & 133.6 & 147.2 & 100,0 & 100,0 & 100,0 \\
\hline $\begin{array}{l}\text { Yüksek Teknolojili Ürün- } \\
\text { ler }\end{array}$ & 4.9 & 4.7 & 5.7 & 3,6 & 3,5 & 3,9 \\
\hline $\begin{array}{l}\text { Orta Yüksek Teknolojili } \\
\text { Ürünler }\end{array}$ & 42.7 & 44.2 & 50.9 & 31,8 & 33,1 & 34,6 \\
\hline $\begin{array}{l}\text { Orta Düşük Teknolojili } \\
\text { Ürünler }\end{array}$ & 39.7 & 37.9 & 41.6 & 29,5 & 28,3 & 28,3 \\
\hline Düşük Teknolojili Ürünler & 47.1 & 46.8 & 35.1 & 35,0 & 35,1 & 33,3 \\
\hline
\end{tabular}

Kaynak: TÜIK

Tablo 26 Türkiye'nin İthalatta Teknoloji Yoğunluğuna Göre İmalat Sanayi Ürünleri

\begin{tabular}{|l|l|l|l|l|l|l|}
\hline & \multicolumn{4}{|l|}{$\begin{array}{l}\text { Toplam İmalat Sanayi Tutarı } \\
\text { Milyar ABD Doları }\end{array}$} & \multicolumn{2}{l|}{ Yüzde pay } \\
\hline Y1l & 2015 & 2016 & 2017 & 2015 & 2016 & 2017 \\
\hline $\begin{array}{l}\text { Toplam İmalat } \\
\text { Sanayi }\end{array}$ & 166.8 & 133.6 & 147.2 & 100,0 & 100,0 & 100,0 \\
\hline $\begin{array}{l}\text { Yüksek Teknolojili } \\
\text { Ürünler }\end{array}$ & 26.2 & 28.3 & 28.8 & 15,7 & 17,0 & 15,1 \\
\hline $\begin{array}{l}\text { Orta Yüksek Tekno- } \\
\text { lojili Ürünler }\end{array}$ & 73.9 & 75.0 & 78.4 & 44,3 & 44,9 & 41,1 \\
\hline $\begin{array}{l}\text { Orta Düşük Tekno- } \\
\text { lojili Ürünler }\end{array}$ & 44.2 & 42.8 & 62.1 & 26,5 & 25,6 & 32,6 \\
\hline $\begin{array}{l}\text { Düşük Teknolojili } \\
\text { Ürünler }\end{array}$ & 22.4 & 21.0 & 21.3 & 13,5 & 12,6 & 11,2 \\
\hline
\end{tabular}

Kaynak: TÜIK

İhracatta yüksek teknolojili ürünlerin payı \%3-4 arasında çok düşük kalmaktadır. Düşük teknolojili ürünlerin ihracattaki payı \%33'lerde gerçekleşmiştir. İthalatta yüksek teknolojili ürünlerin payı \%15'lerde, ihracattaki payının beş katı iken, düşük teknolojili ürünlerin ithalattaki payı, \%11'lerde ihracattaki payının 1/3'ünü oluşturmaktadır. Bu durum gelişmiş ülkelerin tersi bir durumdur yani, gelişmiş ülkelerde yüksek tekno- 
lojili ürünlerin imalat sanayinin ihracattaki payı yüksek iken düşük teknolojili ürünlerin payı düşüktür. Yüksek teknolojili ürünlerin ihracat talep esnekliği düşüktür, diğer taraftan düşük teknolojili ürünlerin ihracat talep esnekliği yüksek olduğundan Türkiye'nin aleyhine bir durumdur.

İsviçre'nin önde gelen araştırma kurumlarından International Institute for Management Development'ın (IMD) Dünya Rekabet Y1lı̆ 2018 (World Competitiveness Yearbook) raporuna göre, 2016-2017 döneminde Türkiye'nin rekâbet gücü azalmıştır. 340'dan fazla kritere göre yap1lan değerlendirmede Türkiye 63 ülke arasında 2016 yılında 38'inci sırada iken, 2017 yılında 47'inci sıraya gerilemiştir. Brezilya 61. Sırada, Rusya 46. Sirada, yer almaktadır. (World Competitiveness Ranking 1 Year Change, https:/www.imd.org/wcc/world-competitiveness-centerrankings/competitiveness-2017-rankings-results/ Erişim Tarihi:08.02.2018).

Dünya Ekonomik Forumu'nun (World Economic Forum) hazırlamış olduğu Küresel Rekabet Raporu'nda (Global Competitiveness Report) ise Türkiye 2016 yılında 55'inci sırada (138 ülke arasında) iken, 2017 yılında 53'üncü sıraya (137 ülke içinde) yükselmiştir. Rapor'da ilk sırada İsviçre, ikinci sırada Singapur, üçüncü sırada İsveç yer almaktadır. 27'inci sırada bulunan Çin, büyük ölçekli gelişme yolunda olan ülkeler arasında lider pozisyona sahiptir. Diğer BRIC ülkeleri arasında Brezilya 80, Hindistan 40, Rusya ise 38'inci siradadır (The Global Competitiveness Report 2017-2018, /www.weforum.org/reports/the-global-competitiveness-report-2017-2018 (Erişim Tarihi: 08.02.2018).

\section{Sonuç}

Ekonomik Kalkınma, GSYH'in reel artışı şeklinde tanımlanan ekonomik büyümenin yanı sıra ülkenin kurumsal, sosyal, kültürel ve teknolojik alanlarda toplumun daha yüksek düzeyde yaşamsal koşullara ulaşabilmesini ifade eder. Kısaca, toplumun yaşam kalitesinin yükselmesidir.

Ülkelerin ekonomik büyüme ve kalkınmalarını belirlemek için birbirlerini etkileyen beş temel öğe bulunmaktadır: doğal kaynaklar, 
insan kaynakları, sermaye, teknolojik gelişim ve politik çevre. Türkiye bu beş öğeden bazılarında üstünken bazı öğelerde eksikleri vardır.

Sanayileşerek kalkınma stratejisi, planlı kalkınma dönemlerinin temel tercihidir. Bir ülkenin büyümesi için yani GSYH'nin artması için yatırımların yapılması gerekir, yatırımların yapılması için de yurtiçi tasarrufların olması gerekir. Gelir düşükse gelirin büyük kısmı tüketime gideceğinden tasarruf yapmaya para kalmaz bunun içinde gelirin yüksek olması gerekir, tasarruf yapılmazsa gelir artmaz gelir çok olmazsa tasarruf yapılamaz fakirliğin kısır döngüsü olarak adlandırılan bu açmazdan çıkmak için genellikle yurtdışı tasarrufa yani dış borçlanmaya gidilmektedir.

Bir ekonominin kalkınmış olduğunun göstergelerinden birisi de sanayinin milli gelir içindeki payının yüksek olmasıdır. Cumhuriyetin ilk yıllarında sanayinin payı düşük iken(\%10-15) tarımın payı (\%40 ile $\% 50$ arasında) değişmektedir. Tarım kesiminin payı 2016 yılında \%6,9'a düşmüştür, sanayi kesiminin GSYH'daki payı ise \%32,35'e yükselmiştir. Türkiye yaklaşık bir asırlık dönemde sanayileşme açısından önemli adımlar atııştır. Kalkınma stratejilerinde yatırımlar kalkınmanın motoru olarak görülmektedir. Kalkınmada yatırımlara kaynak sağlama açısından tasarruflarda önem arz etmektedir. Türkiye'de toplam tasarrufların GSYH'a oranı 24,4 iken toplam yatırımların oranı ise \%28,2 aradaki tasarruf yatırım farkı 3,8 dış tasarruflarla sağlanmaktadır. Bu da cari açık sorununa yol açmaktadır. Kamu sabit sermaye yatırımlarının 2016 yılındaki payı 2,9'dur. Bu oran Avro Bölgesinde \%2,9 olup Türkiye'nin oranıla aynıdır. Türkiye son dönemde bile hala ithal ikameci sanayileşme stratejiyi uygulamaktadır.

Türkiye'nin ihracatına baktığımızda \%4 tarımsal ürünlerden oluşmaktadır, \%2'ye yakını madenlerden, \%94'ü imalat sanayilerinden oluşmaktadır. Türkiye'de tarım sektörü istihdamın \%20'sini, sanayi kesimi ise \%27'sini oluşturmaktadır. En yüksek ihracat yapılan fasıllara bakıldığında kara taşıtları ve parçaları, makineler, mekanik cihazlar, en yüksek ihracat kalemlerini oluşturmaktadır. Türkiye'nin ithalat yapısına baktığımızda \%14'ü sermaye malları, \%74'ü ara malları, \%12'si tüketim mallarından oluşmaktadır. İthalatın içerisinde ara mallarının oranı çok yüksektir. Türkiye genç nüfusu fazla olan ülkelerden biridir bu demografik fırsat penceresi dediğimiz çalışma çağındaki nüfusu iyi değer- 
lendirip ileri elli yıl içerisinde iyi kullanması gerekmektedir. Çünkü birçok Batılı ülkelerin şu anda yaşamış oldukları nüfusun yaşlanması sorunuyla Türkiye'de ilerleyen yıllarda karşılaşacaktır.

Türkiye tüketim malları üretiminin büyük bir çoğunluğunu yurt içinde üretmeyi başarabilmiş, fakat bu başarıyı ara ve yatırım mallarında sağlayamamıştır. İhracata dayalı bir strateji izlemek için ara ve yatırım malları üretiminin büyük çoğunluğu yurt içinde üretilmelidir.

Kalkınmışlı̆̆n ülkeler arasında karşılaştırılmasında kullanılan göstergelerden biriside İnsani Gelişme Endeksidir. Bu endeksin bileşenleri olan doğumda beklenen yaşam süresi, ortalama eğitim süresi, beklenen eğitim süresi ve satın alma gücü paritesine göre kişi başına GSYH'dan oluşmaktadır. Bu üç bileşeni Türkiye yıllar itibariyle yükseltmiştir ve yüksek insani gelişme grubunda yer almaktadır.

Türkiye'nin son yıllardaki ekonomik performansına baktığımızda enflasyon ve işsizlik konusunda plan hedeflerinin tutturulamadığ görülmektedir. İstihdamı artırıcı ve enflasyonu düşürücü politikalar uygulanması gerekir.

International Institute for Management Development'in (IMD) Dünya Rekabet Y1llığı 2018 raporuna göre Türkiye 2017 yılında rekabet gücü 2016 yılına göre 38. Sırada iken 47. Sıraya gerilemiştir. Türkiye'nin rekabet gücünü arttırıcı stratejiler izlemesi gerekmektedir. 


\title{
EXTENDED ABSTRACT
}

\section{A Critical Look for Economic Development Policy in Turkey}

\author{
Mahmut Küçükoğlu - Hacı Yunus Taş - Hüseyin Ercan \\ Yalova University - Harran University
}

The concept of development is broader than growth and refers to the change in the economic struc-ture of an underdeveloped society, as well as to change its social, cultural and political structures. Economic growth is a real increase in a country's production capacity or real gross domestic prod-uct, which can be measured quantitatively. There is no intervention in growth, while the changes that occur spontaneously in the development will be intervened and directed. Growth does not necessarily require structural change in that economy. The public sector and development efforts can be divided into two periods, from the establishment of the Republic to the present. In the first period, the capacity of the economy is also challenged and serious development and development initiatives can be made. In this period, social development was tried to be taken care of together with economic development. In the second period, the development and investment efforts were mostly left to the market conditions and the development of the private sector was adopted.

There are five basic elements that influence each other to determine their economic growth and development: natural resources, human resources, capital, technological development and the political environment. There are some elements that are missing in Turkey Surface in some of these five elements.The industrialization development strategy is the basic choice of planned development periods. In order for a country to grow, in other words, it is necessary to make investments in order to increase the GDP. If the income is low, most of the income is going to be consumed, so there is no money to make savings.

One of the indicators of the development of an economy is the high share of national income in the national income. While the share of in- 
dustry in the first years of the Republic is low (10-15\%), the share of agriculture (between $40 \%$ and $50 \%$ ) varies. The share of the agricultural sector decreased to $6.9 \%$ in 2016 , while the share of the industrial sector in GDP increased to $32.35 \%$. Turkey has taken important steps in terms of industrialization in the period of about a century. In development strategies, investments are seen as the drivers of development. It is important for savings in terms of providing resources for development. While GDP ratio of total savings rate in Turkey is $24.4 \%$ of total investments $28,23,8$ intervening savings investment gap is provided by foreign savings. This leads to the current account deficit problem. The share of public fixed capital investments in 2016 is 2,9. This rate is $2.9 \%$ rate in the Eurozone is the same as Turkey's. Even in Turkey last period still applies import substitution industrialization strategy.

When we look at Turkey's exports consist of agricultural products $4 \%$, close to $2 \%$ of the mineral is composed of $94 \%$ of the manufacturing industry. The agricultural sector employs $20 \%$ in Turkey, while the industrial sector constitutes $27 \%$. Considering the highest export chapters, land vehicles and their components, machines, mechanical devices constitute the highest export items. 14\% of Turkey's imports of capital goods, we look at the structure, intermediate goods $74 \%, 12 \%$ consists of consumer goods. The ratio of intermediate goods in imports is very high. Turkey is one of the countries with more young population of the working age population, this demographic window of opportunity that we must use to evaluate good good in fifty years forward. Because many Western countries with the problem of an aging population, it currently lived in Turkey will face in the coming years.

It has managed to produce the majority of Turkey's domestic production of consumer goods, but the call failed to achieve this success and in investment goods. In order to pursue an export-based strategy, the majority of intermediate and investment goods production should be produced domestically.One of the indicators used to compare development among countries is the Human Development Index. The expected life expectancy at birth, which is the component of this index, consists of GDP per capita according to the average duration of education, expected duration of training and purchasing power parity. These three compo- 
nents Turkey has increased as the years and is located in the high human development group.

When we look at Turkey's economic performance in recent years is evident that achievement of plan objectives regarding inflation and unemployment. Policies should be implemented to increase employment and reduce inflation.International Institute for Management Development's (IMD) World Competitiveness competitiveness of Turkey in 2017 compared to 2016, according to annual report 201838 Values declined while 47 Pos. Enhancing the competitiveness of Turkey's strategies are required to follow.

In this study ", development and emphasis on growth relationship, highlighted by the economic developments in recent years and started to become a center of attraction especially China, Russia, India, Brazil and some advanced countries of the world by comparing human development indicators and Turkey in terms of competitiveness with Turkey's economy related evaluations will be made.

\section{Kaynakça/References}

André, N., Carmem, F. ve Eliane, A. (2013). Structural change and economic development: Is Brazil catching up or falling behind? No. 211 October UNCTAD/OSG/DP/2013/1.

Başoğlu, U. ve İlker, P. (2002). İktisadi planlamaya giriş. Bursa: Ezgi Kitabevi Yayınları,

Birinci Beş Yıllık Kalkınma Planı (1963-1967) Devlet Planlama Teşkilatı,

Brunat E. ve Xavier R. (2007). Competitiveness and adjustment of the Russian economy: Macro and by sectors dimensions. Economic Change and Restructuring, 40, 65-89 DOI 10.1007/s10644-007-90108

Dağdemir E. U., Karluk, S. R., Adaçay, F. R., Aslan, N. ve Togay, S. (2015). Uluslararası iktisat politikası. Eskişehir: Anadolu Üniversitesi Yayını No: 2918

Erden C., Adaçay, F. R., Kar, M., Taban, S., Günsoy, B., Tosunoğlu, T. ve Aktaş, M. T. (2013). İktisadi kalkınma. Eskişehir: Anadolu Üniversitesi Açıöğretim Yayınları. 
Gautam J., Rundle, M., Rosen, D. ve Takahashi, Y. (1996). China's economic reforms chronology and statistics. Institute for International Economics Working Paper 96-5,

Gross savings (\% of GDP), https://data.worldbank.org/ indicator/ NY. GNS.ICTR.ZS (Erişim Tarihi: 06.02.2018).

http://home.fau.edu/sghosh/web/images/India\%20talk.pdf.

https://data.worldbank.org/indicator/NY.GDP.MKTP.KD.ZG?end=2016\&locations=CN-MO-HK\&start=2016\&view=bar\&year_high_desc$=$ false

https://data.worldbank.org/indicator/NY.GDP.PCAP.CD

https://data.worldbank.org/indicator/SL.UEM.TOTL.ZS (Erişim Tarihi: 08.02.2018).

Öz. S. (2007). Küresel rekabette yeni bir güç: Hindistan. TÜSİAD-T, 11/446,

Özdemir,V. (2013). Türkiye'de planlı kalkınma deneyimleri. https://dumludag.files.wordpress.com/2013/09/ozdemir_planlam a.pdf, (Erişim Tarihi: 01.12.2017).

Özsoylu A. F. ve Neşe A. (2011). Dünya ekonomisinin yeni aktörleri BRIC. Adana: Karahan Kitabevi,

Özsoylu, A. F. (2009). Nasıl başardılar? İrlanda-Çin-Hindistan. Ankara: Destek Yayınları.

Parasız, İ. (1998). 1923'den günümüze Türkiye'de iktisat ve istikrar politikaları uygulamaları. Bursa: Ezgi Kitapevi,

Pınar, A., Önder, İ. ve Gümüş, E. (2015). Maliye politikasi II., Eskişehir: Anadolu Üniversitesi Yayını No: 2826

Sandıklı, A. (2009). Sincan Uygur Özerk Bölgesi'ndeki sorunun kaynakları. Bilgesam Stratejik Araştırma Merkezi, Raporlar

Sezen, S. (2009). Çin'in ikinci uzun yürüyüşü. Ankara: Türkiye ve Orta Doğu Amme İdaresi Enstitüsü Amme İdaresi, Desen Ofset A.Ş,

Taban S. ve Kar, M. (2014). Kalkınma ekonomisi. Bursa: Ekin Yayınevi,.

Taban, S., Günsoy, B., Günsoy, G., Erdinç, Z.ve Aktaş, M. T. (2013). İktisadi büyüme. Eskişehir: Anadolu Üniversitesi Yayını No: 2898

Takım, A. (2011). Türkiye'de 1960-1980 yılları arasında uygulanan kalkınma planlarında maliye politikaları. Maliye Dergisi, 160, 154176. 
Tosun, T. T. (2014). Çin ekonomisinin gelişiminin incelenmesi ve Çin ekonomisinin Türk dış ticaretine başlıca etkileri.Yayımlanmamış Yüksek Lisans Tezi, Okan Üniversitesi Sosyal Bilimler Enstitüsü, Bursa.

TÜIKK (2017). Diş Ticaret İstatistikleri, Aralık http://www.tuik.gov.tr/PreHaberBultenleri.do?id=27783,

World Competitiveness Ranking 1 Year Change(2017), https://www.imd.-org/wcc/world-competitiveness-centerrankings/competitiveness-rankings-results/ Erişim Tarihi:08.02.2018).

Yakut, K., Obuz, Ö., Tepecik, F. ve Yaşar, S. (2015). Türkiye cumhuriyeti iktisat tarihi. Eskişehir: Anadolu Üniversitesi Yayını No: 3084

\section{Kaynakça Bilgisi / Citation Information}

Küçükoğlu, M., Taş, H. Y. ve Ercan, H. (2018). Türkiye'de kalkınmaya yönelik ekonomik politikalara eleştirel bir bakış. OPUS-Uluslararası Toplum Araştırmaları Dergisi, 9(16), 2618-2653. DOI: 10.26466/opus. 497943 